\title{
Ebola crisis has alerted politicians to global health threats, debate hears
}

\author{
Anne Gulland \\ London
}

The Ebola virus epidemic has led to a "seismic political shift" in international attitudes to global health security, says Brian McCloskey, adviser to the United Nations' special envoy on Ebola.

McCloskey, who is on secondment from his job as director of global health at Public Health England, told a debate at the London School of Hygiene and Tropical Medicine that Ebola had "galvanised politicians to realise that health crises go beyond health ... Ebola was a major risk to the global economy."

He said that the Ebola outbreak has been different from the H1N1 influenza pandemic, in that governments did not fear that H1N1 would threaten international financial markets. "Ebola has brought down the economy of west Africa and, not least, it has brought home to world leaders much more quickly than H1N1 how much global health problems are a threat," said McCloskey.

The US president, Barack Obama, launched his Global Health Security agenda in February 2014, several months before the world woke up to the crisis in west Africa, but the Ebola epidemic has given added momentum to the agenda, said McCloskey. Obama told a Global Health Security summit in September that the epidemic showed that outbreaks "anywhere, even in the most remote villages and the remote corners of the world, have the potential to impact everybody, every nation."

Peter Piot, director of the London School of Hygiene and Tropical Medicine, told the audience at the debate that he agreed with McCloskey's assessment. "This is only the second health issue discussed at the UN Security Council; the first was AIDS," he said. "Ebola has been discussed in completely different circles. It was being talked about at the World Economic Forum at Davos and there is a momentum building. Whether it's sustainable or not, I don't know, but we must use this momentum."

McCloskey and Piot warned against using the UN's Mission for Ebola Emergency Response as a model for responding to future outbreaks. Piot said, "We have to be careful we're not going to develop clones of the Ebola response. The next likely epidemic is going to be respiratory or airborne, so it will be completely different."

Both speakers stressed that the epidemic was far from over, as the latest figures from the World Health Organization showed 23539 cases of the disease so far, including 9541 deaths.

Piot also said that opportunities for conducting research during the Ebola epidemic had been missed. "Here, we could have gone a lot faster. The rigidity of the FDA [Food and Drug Administration] was an enormous problem and it discouraged pharmaceutical companies, particularly small biotech firms, from engaging. We have to make sure we are better prepared for the next epidemic. Even if case incidence is declining, not trying to test or evaluate vaccines is not an option," he said.

Meanwhile, a Cochrane review of 17 trials compared different ways of rehydrating patients with Ebola and found that intraosseous and subcutaneous rehydration were viable alternatives to intravenous rehydration. ${ }^{1}$

The review compared intravenous, intraosseous, and subcutaneous forms of parenteral feeding and found that, if peripheral intravenous access can be easily achieved, it is the best way of rehydrating patients because it enables the infusion of larger volumes of fluid than the other routes.

However, finding a vein in a severely dehydrated patient, particularly while wearing full protective equipment, can be difficult, and the review found that the intraosseous and subcutaneous routes were viable alternatives. It also showed that inserting an intraosseous line may be quicker than the intravenous route and is less likely to fail.

1 Ker K, Tansley G, Beecher D, Perner A, Shakur H, Harris T. Comparison of routes for achieving parenteral access with a focus on the management of patients with Ebola virus disease. Cochrane Database Syst Rev 2015;2:CD011386. 